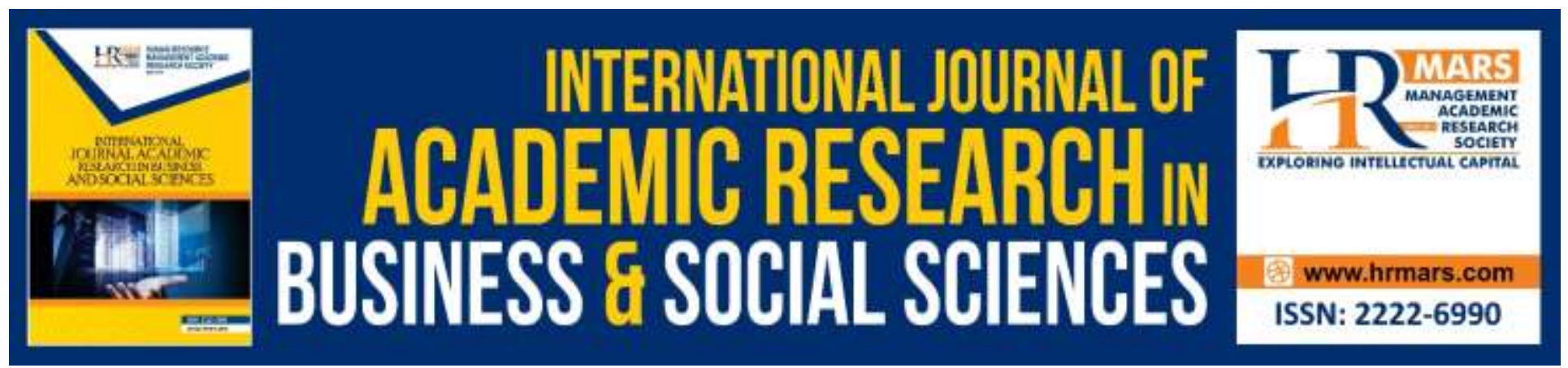

\title{
Conventional Errors in Employing English Prepositions in the Written Work of EFL Jordanian Students
}

\section{Emad Abedalaziz Alwreikat, Kamariah Binti Yunus}

To Link this Article: http://dx.doi.org/10.6007/IJARBSS/v10-i3/7065

DOI:10.6007/IJARBSS/v10-i3/7065

Received: 02 February 2020, Revised: 22 February 2020, Accepted: 12 March 2020

Published Online: 26 March 2020

In-Text Citation: (Alwreikat \& Yunus, 2020)

To Cite this Article: Alwreikat, E. A., \& Yunus, K. B. (2020). Conventional Errors in Employing English Prepositions in the Written Work of EFL Jordanian Students. International Journal of Academic Research in Business and Social Sciences, 10(3), 488-496.

\section{Copyright: (c) 2020 The Author(s)}

Published by Human Resource Management Academic Research Society (www.hrmars.com)

This article is published under the Creative Commons Attribution (CC BY 4.0) license. Anyone may reproduce, distribute, translate and create derivative works of this article (for both commercial and non-commercial purposes), subject to full attribution to the original publication and authors. The full terms of this license may be seen

at: http://creativecommons.org/licences/by/4.0/legalcode

\section{Vol. 10, No. 3, 2020, Pg. 488 - 496}

Full Terms \& Conditions of access and use can be found at http://hrmars.com/index.php/pages/detail/publication-ethics 


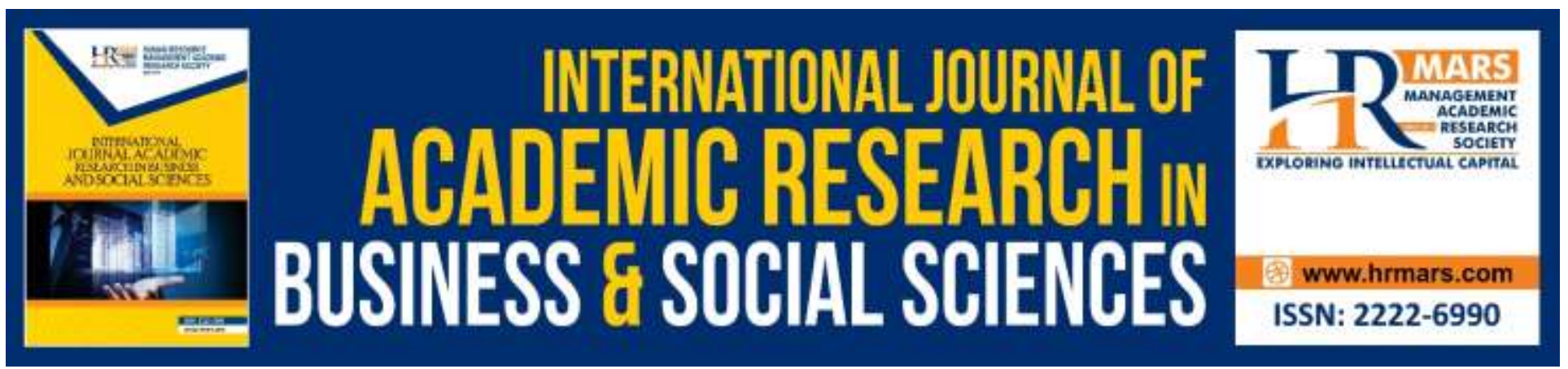

\title{
Conventional Errors in Employing English Prepositions in the Written Work of EFL Jordanian Students
}

\author{
Emad Abedalaziz Alwreikat, Assoc. Prof. Dr. Kamariah Binti Yunus \\ Faculty of Languages and Communications, Universiti Sultan Zainal Abidin, 21030 kuala Nerus, \\ Terrengganu, Malaysia. \\ Email: emadwrikat@yahoo.com,kamariah@unisza.edu.my
}

\begin{abstract}
This paper reviews the status of learning and teaching English prepositions in the Arab word and especially in the Jordanian context. However In this process of learning English preposition, Jordanian EFL learners in the attempt to master this part of speech faces different difficulties.

Through the related literature of the studies conducted on these difficulties it was suggested that the majority of errors made by the Jordanian EFL students are the results of frequent acquisition and learning process, such as simplification of the target / English language prepositions system and rules overgeneralization. The impact of the subjects' native language was found crucial. Where most of the errors that could possibly be ascribed to native language transfer, among other sources, such as the prepositions/in/, / into/ and /at / matches / Fe/, /onto/ and /on/ matches/ala/ in the Arabic language where the preposition /of/ is with no match, because of its diverse structural function.
\end{abstract}

Key words: Prepositions, Error Analysis, Interlingual Interference, EFL, Language Acquisition

\section{Introduction}

English language is considered as one of the most important languages worldwide and the tool for the economical and global development .It has, however, grown to be as an essential language in all walks of life (Zughoul, 2002). EFL has become a subject matter of research and study for many scholars and researchers in the Arab world particularly Jordan (Khawaldeh, 2005).

English as a foreign language is the medium of instruction in government and public schools in Jordan. Students start taking English as a school subject right from the first year of their study at school, and by the end of the compulsory stage of education, the students would have spent about ten years of learning EFL. By the end of this period, they are expected "to understand simple English, to communicate sensibly with an English speaking person within certain reasonable areas, to read, understand, and speak simple English with ease, as well as write a paragraph in English using basic structures of the language "(Zughoul, 2002). 
INTERNATIONAL JOURNAL OF ACADEMIC RESEARCH IN BUSINESS AND SOCIAL SCIENCES Vol. 10, No. 3, March, 2020, E-ISSN: 2222-6990 @ 2020 HRMARS

In Jordan, the researcher has observed that, in spite of the fact that they have studied English for more than five years and that their vocabulary ranges from 2000 to 3000 words, but still most students of EFL do not have the ability to construct a correct paragraph using adequately the basic structures of the English language. This means that one or more of the objectives defined in the Jordanian Curriculum has not been achieved. And the "dream" of the EFL teacher of a good student is shattered by the poor results attained by the students. (Habash, 1982)

However why do learners still find difficulties in learning English in spite of their teachers best effort to help them in achieving good results? Is the question which arises here. So the answer to this question lies in the fact that learning English or any other foreign language is difficult, not only for the Jordanian students mentioned in this study, but for all non-native speakers. The main issue is that, even in his very first lesson, EFL student does not start learning the L2 from zero or a neutral point (Bitchener et al., 2005).

In Jordan, the new philosophy and methodology of teaching English were hastily imported and adopted with the help of local linguists.; in which it caused a great deal of damage to English language teaching by introducing or writing inferior English textbooks for schools(Zughoul, 2003). In addition, it is estimated that;

"We seem to be facing the following major problems: the inadequacy of the language components, the usefulness of much of linguistics components, and the insufficiency and /or inappropriateness of the literature components".

Nevertheless, the most significant feature that obstructs good education, in my point of view, is the curriculum schoolbooks that are used in Jordan since, firstly, these books lack interest and, secondly, they lack enough exercises, especially on prepositions, which are one of the areas with which the Jordanian subjects of this study have great difficulty. An analysis of these schoolbooks used by the learners obviously illustrates the absence of clear and rich drills and explanations on the proper use of English prepositions. Accordingly, these students do not obtain an opportunity to learn the prepositions appropriately or to use them accurately, particularly in their written work.

The other major problem hampering good teaching is the fact that EFL teachers in local schools are not prepared to handle the variety of errors that occur in students' speech and writing. Which suggest that EFL Jordanian instructors are not familiar of the language learning and teaching models underpinning the Jordanian EFL curriculum (Alkhawaldeh, 2005).

In this study, this researcher tries to define the key source of difficulties which Jordanian EFL students face in using prepositions. Consequently, the main focus of this research lies in going a further step to investigate and gain a complete understanding of this problem. Systematically investigating the errors allows us to: Recognize the learners' strategies used in language teaching, Distinguish the reasons of learner errors, and gain evidence on the common difficulties in the process of language learning as an aid to the course of teaching or in the teaching resources development. Accordingly, learners' errors are always been considered of interest and important to instructors, syllabus designers and assessment developers. This will eventually lead educators to develop proper materials and effective teaching methods, and constructing assessments suitable for different levels (Richards, 1974; Corder, 1986; Brown, 2000). 
INTERNATIONAL JOURNAL OF ACADEMIC RESEARCH IN BUSINESS AND SOCIAL SCIENCES Vol. 10, No. 3, March, 2020, E-ISSN: 2222-6990 @ 2020 HRMARS

\section{EFL Status in Jordan}

The EFL context in Jordan was affected by the international developments in the methodology of teaching a foreign language. Before, 1962; the EFL teaching in Jordan was marked by the use of a mixture of traditional methods and the lack of the adoption of a systematic approach in the classroom. By the 1971 the EFL field used a modified structural approach. It was not until the year 1984 when the communicative approach was officially adopted in the country (Kailani, 2004).

In addition, Mukattash (2003) whispered that the majority of Arab countries including Jordan used to teach through the grammar translation method and the direct method where they recently adopted the communicative approach. On the other hand, this might mean that practitioners in the field of EFL might not be aware of the linkage between language learning theories and language teaching methods.

\section{Objectives of the Study}

As discussed earlier in the introduction, this study aims to investigate the Common Errors in the Use of English Prepositions that EFL Jordanian students face and the influence of the speakers' mother tongue and the role of the teacher in dealing with this error.

Unfortunately most of foreign language instructors are not aware of the conventional errors made by the students. Still, it is not enough to be aware of the students' errors forms to find out at the most accurate way of good, remedial and preventive teaching (Labah, 2006). Furthermore language teachers want to understand the reasons of these errors and the causes of their continuous occurrence with changed groups of students.

In this manner, additional light can be shed on the parts to which more care and emphasis in the teaching and learning process in order to overcome and avoid these expected complications. For all mentioned reasons, conducting research is essential, and error analysis is the best instrument for unfolding and clarifying errors made by FL speakers (Johanson, 1975).

Moreover, error analysis is a comparative procedure, a distinct case of contrastive analysis, which makes its starting point the same message expressed in two languages: the students L1 and L2. One of its theoretical objectives is the psychological description of how errors are originated in relation to the student's strategies and of the learning process itself. The second objective is related to the linguistic description of these errors (Corder, 1973).

Furthermore, the benefits of using error analysis in English language teaching are two. Firstly, it gives evidence on the learners' difficulties at different points in their second language acquisition. This evidence is significant so that proper courses and new teaching materials can be developed and constructed. Secondly, error analysis demonstrates the learner's way of learning and what his builtin syllabus is (i.e. in what order and when different learners acquires L2 forms and instructions). This information can help teachers ... to adapt themselves to his (the learner's) needs rather than impose upon him their (the teachers') preconceptions of how and when he ought to learn.( Corder, 1974: $p$. 27).

On the other hand, international studies addressed the problem of the study in different ways like: (Gocsik, 1999) presented a paper on addressing specific problems in learning English as a second language. She mentioned that the top ten list of common ESL errors specified prepositions as number two. She added that ESL writers were reported to commit errors in prepositions as they had problems understanding the difference between the various prepositions that they had studied. 
INTERNATIONAL JOURNAL OF ACADEMIC RESEARCH IN BUSINESS AND SOCIAL SCIENCES Vol. 10, No. 3, March, 2020, E-ISSN: 2222-6990 @ 2020 HRMARS

(Lakkis and Abdul Malak, 2000) analyzed the transfer of prepositions in Arabic language to English. Their test was conducted on 55 students of the American University of Beirut. All the respondents' L1 is Arabic; they explored the extent of transfer of L1 to the use of second language in the usage of prepositions. In their report, it was proved that similarities between Arabic language and English language helped learning while differences which hinder learning ought to be pointed out to the students, rules of prepositions should be taught which could simplify the usage of prepositions. They also stressed that continuous exposure to correct prepositional usage could also help promote the correct usage of the prepositions among the second language learners.

(Cranmer, 2000) claimed that he encountered common errors in prepositions as below:

i) - Students were confused over (in) and (on) in basic spatial contexts.

ii) - Students were spotted using (since) instead of (from) when followed by (to, till, until).

The errors committed by EFL learners could be concluded as usually on the three following kinds:

A) - omission of an obligatory preposition in English.

b) - Insertion of redundant preposition in English.

c) - Choice of a wrong prepositions in English.

Additionally, the errors that learners of EFL are expected to make are due to several different causes. Among these there are two main ones both of which have been mentioned above. The first is affected by interference from the L1 and the second is produced by interference from other structures in the L2. The first type of error arises when a student of $L 2$ carries over the practices of his mother tongue into the L2. This means that his L1 practices (forms, systems or instructions) interfere or preclude the student from gaining the forms and structures of the second language (Labah, 2006).

Secondly, this type of error is initiated by the interference of the target language itself. This is called "interlingual interference". Some of these errors are due to the structure of the L2 and not the L1 in which they are characters of incorrect hypotheses. The students, in this case, "... try to derive the rules behind the data to which they have been exposed, and may develop hypotheses that correspond neither to the mother tongue nor to the target language" (Richards, 1974).

In other words, irregular or ill-formed sentences are formed by incorrectly applying their awareness of $L 2$ forms and structures to the new situations. At this point, this study is singly concerned with prepositional errors and only a limited number of these prepositions also. English prepositions previous studies to some extent; have highlighted the difficulties of English prepositional usage for all non-native learners. "There is a general consensus among teachers of English as a foreign language concerning the difficulty of prepositions" (Zughoul, 1979).

"English language teachers and researchers are well aware that English prepositional usage; is one of the most difficult areas for students of EFL" (Khampang, 1974).

Moreover, Prepositions are an ever-lasting problem for foreign learners of English (Mukattash, 1976). English prepositions are difficult for any EFL students because they usually relate them to their own MT prepositional system. The difficulty is also caused by the difference in number, meaning and usage of the prepositions in the MT and EFL. Parts of speech (especially verbs) play a distinguish role in the omission, addition and selection process of a incorrect preposition, in which will affect the whole meaning of the learners planned idea. Additionally, the idiomaticity of English prepositions marks them as problematic to learn even by native speakers. Arab learners are also expected to find similar difficulties in the use of English prepositions because although Arabic and English prepositions have some characteristics in common, they differ in both number and usage 
INTERNATIONAL JOURNAL OF ACADEMIC RESEARCH IN BUSINESS AND SOCIAL SCIENCES Vol. 10, No. 3, March, 2020, E-ISSN: 2222-6990 @ 2020 HRMARS

\section{The Importance of English Language in Jordan}

The growing importance of English as a world first language is difficult to deny. English is used in every sector in academy, industry, trade, etc. Throughout the last decades the world is becoming smaller, and individuals of the world are more interacting with each other.

English is described as the international, common language for commercial, technology and politics, for that Jordan's economic future is influenced by increasing Jordanian English capabilities (Ministry of Education, 2003).

Likewise, English is defined as the world's most widespread language. So it is difficult to estimate the exact number of English speakers. But the significance of English is not just in the number of speakers but also in what it is used for. In Jordan, the first language spoken is Arabic and the foreign language spoken most widely is English due to political and technological considerations (Alkhawaldeh, 2005) English is the major language of new media such as the Internet and electronic mail are defining the communication challenge and needs for corporate Jordan. The majority of new technological and scientific advances are written in English in order to reach as many people as possible. All of the major business resources published in English such as Times, CNN, The Wall Street Journal and Newsweek are used as a valuable business resource for many countries around the world.

Additionally, the need for English in the Arab world is to communicate with the world and for development in its broadest sense. Teaching this language for these purposes and in these circumstances necessitates some changes in approach, perceptions, methodology and curriculum at large. These changes stress the consolidation of the mother tongue teaching, stressing localizing the content and making it relevant to the Lerner, keeping the status of English as foreign language and making the best of what other countries proposed in their foreign language teaching policies (Zughoul, 2003).

\section{Prepositions}

Preposition is an element of the eight parts of speech. Specifically, it is a connector: which functions to link a noun or pronoun (the object of the preposition) to additional word in a sentence. Likewise, it demonstrates how the noun or pronoun object is related to other words. Accordingly, preposition cannot stand alone: it must always be enclosed within a phrase termed a prepositional phrase. Typically, prepositions show relations of direction, location, and time, also they can express other relations as well (the prepositions, but, except, without. show a relationship of exclusion).

Commonly used prepositions: until, beside, for, since, about, below, from, to, across, beneath, in, toward, after, behind, inside, against, through, between, into, under, along, beyond, like, above , among, by, near, up, around, down, of, upon, at, during, off, with, before, except, on, within

These examples of prepositions show how a relationship to a word is made in the rest of the sentence.

- Rama likes to play on the monkey bars.

"On the monkey bars" is the prepositional phrase. It is a modifier that tells us where Rama likes to play. It modifies the verb "to play."

Examples of Prepositional Phrases:

1. Rama fell on the floor. (direction)

2. Aziz retired after his eighteenth birthday. (time)

3. Halla is standing beside her mother. (location) 
4. Abood and his friends finished the Math exam within an hour. (time)

Sometimes prepositions occur as combinations as in the following examples ahead of, in case of, as a consequence of, in the course of, on behalf of, in advance of, instead of, in addition to, because of, regardless of, in care of, in comparison with, according to, apart from, for fear of, next to, in favor of, with the exception of, up against, at the risk of, along with, in spite of, in connection with, together with, as a result of

Examples of compound prepositions

1. As a result of the war, we had to move out of our home.

2. Instead of going to Iraq this summer, we are going to Jordan.

\section{Prepositions Misuse}

In process of learning English preposition, Jordanian EFL learners justifiably attempt to relate them to the lesser number of Arabic prepositions and to Arabic structure. Therefore, the first problem for these learners lies in the point that not every Arabic preposition has a fixed equal in English and vice versa, secondly, not every preposition in both English or Arabic has a fixed usage and meaning, demonstrating time or space or following / preceding a definite word. As a sample, (Fii) the Arabic preposition is used as an equal of "during, on, at, into, in, within, inside" and the zero equivalent (?). This specific preposition has consequently excessive semantic power in standard and colloquial Arabic: it is the filter through for all these English equivalents. It signifies time and place and comes with numerous different Arabic words in abstract and figurative usages. Therefore, (Fii), as well as other Arabic prepositions, interferes in the selection and usage of English ones, as illustrated by the following examples which occurred in the students compositions.

1. Aziz slept (in) bed. (Correct response) (In)

2. Spring begins in the first of March. (On)

3. In the end of the journey Abood bought fruit. (At)

4. In her last holiday Rama did many different things. (During)

5. Halla went home in happily. (? )

The first English preposition that is likely to be produced as the equivalent of the Arabic preposition Fii is "in" as presented by sentence 1 where it is correctly used. Nevertheless, it is wrongly selected instead of "on", "at", "during" and "?" in sentences 2.3.4 and 5.

Additionally, Jordanian EFL learners use or ignore certain English prepositions according to Arabic structures. Therefore, by literal translation, the researcher notices that when the Arabic context involves a preposition (or involves none); students make incorrect answers, as demonstrated in these examples:

Gutla rajulun filmadeenah....... A man killed in / at the town.

Wajdutu rajulun filtareeq.......... met a man in / on the way.

Other form of errors that arises with Jordanian EFL learners as well as any other learners of English as a foreign language, regardless their mother tongue - is caused by the interference of English itself. Note the following examples:

1. Aziz came back at home. (?)

2. Abood visited to Hisham Place. (?)

3. Rama asked to her father. (?)

4. Halla likes to listen at music. (to) 
These answers are not the cases of L1 interference, since their Arabic literal translation does not indicate these inaccurate answers. As a result, they are in the second class of error. The learner who was taught "He came back (to) his house" and "we remained (at) the house", will create, without any consideration of the structure, 'Abood visited to Hisham Palace' or 'Aziz came back at home'. Also, as seen in the third example, the learner who has learnt 'He said (to) his father' produces 'Rama asked to her father' due to what he sees as a resemblance of the two verbs of speech "said" and " asked". 'The student, facing a specific preposition with one form of verb, tries to use the same preposition with related verbs'. E.g. "She said (to) Aziz "leads to "She asked to Aziz".

In this, the learner creates an irregular usage constructing on his previous knowledge of English. After studying the English constructions "look at" and " at the grocer's", EFL students may produce an unusual structure like "listen at music" or " a friend at my father's" as illustrated in sentences 4 and 5. These mistakes are established on contrasts within the English language itself.

\section{Conclusion}

This study is designed to investigate the types and causes of errors made by Jordanian EFL students in the use of prepositions. The research findings revealed that the majority of errors made by the subject students are the results of frequent acquisition and learning process, such as simplification of the target / English language prepositions system and rules overgeneralization. The impact of the subjects' native language was found crucial.

Moreover, in the light of the students errors it can be concluded that most of the errors could possibly be ascribed to native language transfer, among other sources, such as the prepositions /in/, / into/ and /at / matches / Fe/, /onto/ and /on/ matches /ala/ in the Arabic language where the preposition /of/ is with no match because of its diverse structural function. Besides, Arabic Language prepositions are not of multi-meanings and functions as the English ones. On the other hand some students were found to invent a deviant usage building on his previous experience of English.

For that the researcher recommend that instructors of EFL start teaching the English prepositions from the beginning as a method and not just as at present a random group of unrelated words. In other words, instructors should present prepositions as a group with their meanings and usage, they should be presented in the classroom within intensive drilling and should also be recognized and clarified.

Moreover, miscellaneous prepositions should be explained thoroughly, since these prepositions can be understood only through emphasizing and presenting their usage within the nouns, adjectives or verbs involved to them in the same phrase.

Furthermore, educators ought to know the system that governs and affect prepositions in both languages and are recommended to test and error analysis their students work to become acquainted with the common errors to be able to apply corrective treatment if necessary.

Additionally, students' awareness and understanding of their own errors is very essential and valued. Students should know the source and reason of these errors. Also, it is important to present the cause of these errors through studying the uses of each preposition in the aim of making the students distinguish them from each other.

To sum up, the Conclusion made through the Common Errors In the written work of Jordanian EFL students in the Use of English Prepositions indicates that there is an essential need for comprehensive modifications in the curriculum design and teaching approaches applied. 
INTERNATIONAL JOURNAL OF ACADEMIC RESEARCH IN BUSINESS AND SOCIAL SCIENCES

Vol. 10, No. 3, March, 2020, E-ISSN: 2222-6990 C 2020 HRMARS

\section{References}

AlKhawaldeh, A. H. (2005). Jordanian English Language Teachers' Awareness of Language Learning Theories and Teaching Methods. Mu'tah Lil-Buhuth wad-Dirasat,Vol 20, No. 7.

CORDER, S. P. (1973) Introducing Applied Linguistics. London: Hazel Watson and Viney Ltd., CORDER, S. P. (1974) “The Significance of Learner's Errors”, in Richards (ed.), 19-27.

Cranmer, D. (2000). Some approaches to written correction, V11. London: The British Council Journal. Eissa, Labah. (2006) "ARAB POSTGRADUATE STUDENTS, AS SPEAKERS OF ESL ERRORS IN THE USE OF PREPOSITIONS AND ADVERB PARTICLES: Universiti Sains Malaysia (USM).

Gocsik, K. (1999) addressing specific problems: English as a second language.

Habash, A/Salam, Zeinab, (1982). Common Errors in the Use of English Prepositions in the work of UNRWA students. Birzeit University

Johanson, Stig. (1975): "The Uses of Error Analysis and Contrastive Analysis I. "English Language Teaching, 246- 253.

Kailani, T. Z. (2004). A synthesized Pedagogical Methodology for English Classroom, Available online at: $\quad$ http://search.epnet.com/direct.asp?an=9602150564\&db=ufh

Khampang, Phon. (1974): "Thai Difficulties in Using English Prepositions. "Language Learning, 215222.

Lakkis, Malak, A. (2000). Understanding the Transfer of Prepositions: Arabic to English. Forum, v38 n3 Jul-Sep 2000.

Mukattash, Lewis. (1976) A Pilot Project In Common Grammatical Errors in Jordanian English. Amman: The University of Jordan.

Mukattash, L. (2003). Towards a New Methodology for the Teaching of English to Arab Learners, International Journal of Arabic English Studies(TEAL), Vol.4, pp.211-235.

RICHARDS, J. C., and Sampson, G. P. (1974) "The Study of Learner English", in Richards (ed.), 3-18.

Zughoul, M. R. (2002). The power of Language and the Language of Power in Higher Education in the Arab World. Conflict, 'Dominance and Shift' College of Islamic and Arabic Studies Journal. 23.

Zughoul, M. R. (2003). Zughoul, M. R., (2003). Globalization and EFL/ESL Pedagogy in the Arab World. Journal of Language and Learning, 1, 2, 2003 